NBER WORKING PAPER SERIES

\title{
THE FLIGHT-TO-LIQUIDITY PREMIUM IN U.S. TREASURY BOND PRICES
}

\author{
Francis A. Longstaff \\ Working Paper 9312 \\ http://www.nber.org/papers/w9312
NATIONAL BUREAU OF ECONOMIC RESEARCH 1050 Massachusetts Avenue
Cambridge, MA 02138
October 2002

I am grateful for helpful discussions with Jun Liu, Yoshihiro Mikami, Pedro Santa-Clara, Eduardo Schwartz, Abraham Thomas, Toshiki Yotsuzuka, and seminar participants at Greenwich Capital Markets and Simplex Asset Management. I am particularly grateful for the many valuable comments and insights of an anonymous referee. All errors are my responsibility. The views expressed herein are those of the authors and not necessarily those of the National Bureau of Economic Research.

(C) 2002 by Francis A. Longstaff. All rights reserved. Short sections of text, not to exceed two paragraphs, may be quoted without explicit permission provided that full credit, including $\mathbb{C}$ notice, is given to the source. 
The Flight-to-Liquidity Premium in U.S. Treasury Bond Prices

NBER Working Paper No. 9312

Francis A. Longstaff

October 2002

\begin{abstract}
$\underline{\text { ABSTRACT }}$
We examine whether there is a flight-to-liquidity premium in Treasury bond prices by comparing them with prices of bonds issued by Refcorp, a U.S. Government agency, which are guaranteed by the Treasury. We find a large liquidity premium in Treasury bonds, which can be more than fifteen percent of the value of some Treasury bonds. This liquidity premium is related to changes in consumer confidence, the amount of Treasury debt available to investors, and flows into equity and money market mutual funds. This suggests that the popularity of Treasury bonds directly a.ects their value.
\end{abstract}

Francis A. Longstaff

UCLA

Anderson Graduate School of Management

110 Westwood Plaza, Box 951481

Los Angeles, CA 90095-1481

and NBER

francis.longstaff@anderson.ucla.edu 
But what is crucial about this distinction is that the individuals who were moving from, let's assume, the illiquid U.S. Treasuries to the liquid on-the-run liquid issues, are basically saying, "I want out. I don't want to know anything about whether a particular investment is risky or not. I just want to disengage." And the reason you go into these liquid instruments is that that is the vehicle which enables one to disengage as quickly as possible.

- Alan Greenspan, October 7, 1998.

\section{INTRODUCTION}

Historically, fixed income markets have often experienced what are termed flights to quality where some market participants abruptly want to decrease their portfolio exposure to securities bearing credit risk. Bank runs and panics, credit crunches, and sudden declines in the market values of corporate bonds are all examples of the effects of a flight to quality. ${ }^{1}$ From an asset pricing perspective, of course, the decrease in the value of risky debt resulting from a flight to quality can readily be explained in terms of changes in perceived default probabilities and in the equilibrium required premium for bearing credit risk. ${ }^{2}$

In recent years, however, a related but distinct phenomenon has been observed in the world's financial markets: flights to liquidity. In a flight to liquidity, some market participants suddenly prefer to hold highly-liquid securities such as U.S. Treasury bonds rather than less-liquid securities. This is consistent with recent papers by Woodford (1990), and Holmström and Tirole $(1996,1998)$ who examine the role of the public sector in providing liquidity to financial markets. A recent example of a flight to liquidity was in the wake of the 1998 Russian default where Treasury bonds suddenly

\footnotetext{
${ }^{1}$ As examples, see Diamond and Dybvig (1983) and Bernanke and Gertler (1995).

${ }^{2}$ As examples, see Duffie and Singleton (1997, 1999), Duffee (1999), and Liu, Longstaff, and Mandell (2001).
} 
increased in value relative to less-liquid debt instruments, causing credit spreads to widen and resulting in major losses at Long Term Capital Management and many other highly-leveraged hedge funds. Of course, there may have been elements of both a flight to quality and to liquidity during the 1998 hedge fund crisis.

Given that flights to liquidity may occur, however, it is important to consider what effects a pure flight to liquidity may have on security prices. Standard asset pricing theory implies that the value of a security should equal the present value of its cash flows, and should not depend on how popular the security is as a trading vehicle. More specifically, if two securities have identical cash flows in all states of the world, then the two securities should have the same value even if one suddenly becomes more popular among investors during a flight to liquidity. Finding evidence of a significant flight-to-liquidity premium in the price of the more popular security would pose a challenge to traditional asset pricing theory.

This paper examines whether there are flight-to-liquidity premia in U.S. Treasury bond prices. In doing this, we compare Treasury bond prices with the prices of bonds issued by the Resolution Funding Corporation (Refcorp), a government agency created by the Financial Institutions Reform, Recovery, and Enforcement act of 1989 (FIRREA). Refcorp bonds differ from most other agency bonds (which usually bear some small credit risk) in that their principal is fully collateralized by Treasury bonds, and that full payment of coupons is guaranteed by the Treasury under the provisions of FIRREA. ${ }^{3}$ Thus, Refcorp bonds literally have the same credit risk as Treasury bonds. Since Treasury bonds are more liquid and thus popular among investors (particularly during flights to liquidity), comparing their prices with those of Refcorp bonds provides an ideal way of testing whether there are flight-to-liquidity premia in Treasury bond prices.

The results are surprising. We find that during the past decade, there are often large liquidity premia in Treasury bond prices. In some cases, these premia can represent as much as 10 to 15 percent of the value of the Treasury bond. ${ }^{4}$ An exploratory

${ }^{3}$ In general, bonds issued by government sponsored enterprises such as Fannie Mae, Freddie Mac, and the Federal Home Loan Bank are not explicitly guaranteed by the U.S. Treasury and presumably carry some small amount of credit risk.

${ }^{4}$ Although our focus is different, these results also parallel and complement the findings 
analysis reveals that these flight-to-liquidity premia are related to a variety of market sentiment measures such as changes in consumer confidence and in the amount of funds flowing into equity and money market mutual funds. Furthermore, the flightto-liquidity premia are directly related to changes in the supply of Treasury securities available to investors resulting from the recent Treasury buyback program. We argue that these results are unlikely to be explained by differences in tax treatment, perceived credit risk, transaction costs, repo financing costs, or legal and regulatory restrictions on bondholders. These results have important implications for current asset pricing models.

The remainder of this paper is organized as follows. Section 2 describes the Refcorp bonds. Section 3 discusses the data used in the study. Section 4 conducts the empirical analysis. Section 5 evaluates alternative explanations for the results. Section 6 makes concluding remarks.

\section{REFCORP BONDS}

Refcorp was established by Title V of FIRREA in 1989. The sole purpose of Refcorp was to provide funding for the Resolution Trust Corporation (RTC) which was created in the aftermath of the savings and loan crisis of the late 1980s as a means of liquidating insolvent institutions. Until October 29, 1998, Refcorp was subject to the Thrift Depositor Protection Oversight Board. At that time, the Oversight Board was abolished and its authority transferred to the Secretary of the Treasury. The day-today operations of Refcorp are under the management of a three-member committee composed of the Director of the Office of Finance of the Federal Home Loan Banks and two members selected from among the presidents of the twelve Federal Home Loan Banks. Refcorp is simply a financing vehicle and is not allowed to have any paid employees. $^{5}$

of Amihud and Mendelson (1991), Kamara (1994), Jordan and Kuipers (1997), and others who show that liquidity effects may explain differences in the prices of otherwise identical Treasury securities.

${ }^{5}$ This summary is based on the description of Refcorp given on pages 1235-1236 of the Appendix to the Budget of the United States Government for Fiscal Year 2002. 
Beginning in 1989, Refcorp issued six issues of bonds with fixed coupon rates ranging from 8.125 to 9.375 , and with final maturity dates ranging from October 15, 2019 to April 15, 2030. These bonds are listed in Table 1. As shown, the principal amounts outstanding of these issues range from $\$ 4.5$ billion to $\$ 5.5$ billion, making these issues comparable in size to many Treasury bond issues. The total principal amount of Refcorp bonds outstanding is $\$ 29.5$ billion. As with most recently-auctioned Treasury bonds, Refcorp bonds are eligible to be held in stripped form in the Federal Reserve book-entry system. ${ }^{6}$ Refcorp bonds receive the same tax treatment as U.S. Treasury bonds. In particular, Refcorp bonds are taxable for Federal income tax purposes, but interest income from these bonds is exempt from state tax. ${ }^{7}$

From the proceeds of these bond issues, Refcorp purchased a special domestic series of long-term zero-coupon bonds issued by the Treasury which are pledged to pay the principal amount of the Refcorp bonds. Thus, the principal amounts of the Refcorp bonds are completely defeased by the Treasury zero-coupon bonds. Under FIRREA, and later under the Gramm-Leach-Bliley Act of 2000, the Federal Home Loan Bank system is required to pay some portion of the coupons on the bonds, and thus, coupon payments on Refcorp bonds represent a senior claim on the Federal Home Loan Bank system. To the extent that the payments from the Federal Home Loan Bank system are not sufficient to pay the coupon payments on the Refcorp bonds, however, FIRREA and the subsequent Gramm-Leach-Bliley Act require the Treasury to pay to Refcorp the additional amounts needed to pay the coupon payments. Through March 2000, the Treasury has actually paid more than 75 percent of the annual interest owed on the Refcorp bonds. ${ }^{8}$ Thus, while the Refcorp bonds are not explicitly backed by the full faith and credit of the U.S. government, repayment of both the coupon payments and principal amounts of the bonds is, in fact, implicitly guaranteed by the U.S. Treasury. An immediate implication of this is that the credit risk of Refcorp bonds is virtually

${ }^{6}$ The Treasury STRIPS program is described in Grinblatt and Longstaff (2000) and Jordan, Jorgensen, and Kuipers (2000).

${ }^{7}$ In some states, capital gains on Treasury and agency bonds are taxable. In other states, however, these capital gains are not taxable. We are grateful to the referee for pointing this out.

${ }^{8}$ See page 17435 of the Federal Register, Vol. 65, No. 64, April 3, 2000. 
the same as that of Treasury bonds.

\section{THE DATA}

Both U.S. Treasury bonds and Refcorp bonds can be held in stripped form and markets for both Treasury and Refcorp zero-coupon bonds exist. To measure the size of the flight-to-liquidity premium, we subtract the yields on Treasury zero-coupon bonds from the yields for zero-coupon Refcorp bonds with corresponding maturities. The advantage of using zero-coupon bonds in this analysis is that it allows us to avoid any possible bias introduced by comparing yields on bonds with different coupon rates. By estimating the liquidity premium as the difference in yields between Treasury and non-Treasury bonds, this paper differs from earlier papers such as Kamara (1988), Amihud and Mendelson (1991), Boudoukh and Whitelaw (1991), Longstaff (1992), and Kamara (1994), which compare the yields on different Treasury bonds. This is important because it allows us to uniquely identify the size of the liquidity premium associated with bonds issued by the U.S. Treasury. ${ }^{9}$

The data consist of monthly (month-end) observations of yields for Treasury and Refcorp zero-coupon bonds for the ten-year period from April 1991 to March 2001. The data are obtained from the widely-used Bloomberg system. This system gathers quotations for both Treasury and Refcorp zero-coupon bonds on an ongoing basis from a variety of bond dealers and financial institutions. Because of the high liquidity of the Treasury bond market, prices for Treasury zero-coupon bonds are available from more than two dozen sources on an intraday basis. In contrast, the liquidity of Refcorp zero-coupon bonds is much lower. Despite this, however, there are typically at least seven or eight sources that provide intraday or daily pricing information for Refcorp zero-coupon bonds. To verify that the pricing information is reliable, we checked a number of the sources providing Refcorp zero-coupon bond prices and confirmed that the prices are updated on an intraday basis within the Bloomberg system.

\footnotetext{
${ }^{9}$ Other relevant papers about the effects of liquidity on asset prices include Lippman and McCall (1986), Boudoukh and Whitelaw (1993), Longstaff (1995, 2001), Brenner, Eldor, and Hauser (2001), and Holmström and Tirole (2001).
} 
Since the coupon payment dates for Refcorp bonds are generally one month offcycle from those for Treasury bonds (Refcorp zero-coupon bonds are on a January, April, July, October cycle while Treasury bonds are typically on a February, May, August, and November cycle), it is not possible to compute the yield spread from exactly-matched maturities. Thus, some interpolation of the Refcorp and Treasury zero-coupon yield curves is needed to be able to estimate the flight-to-liquidity premia. Specifically, we calculate these premia by taking the differences between the constant maturity .25, .50, 1, 2, 3, 4, 5, 7, 10, 20, and 30 year points on the Bloomberg fair value curves for Refcorp and Treasury zero-coupon bonds. These fair value curves are estimated by the Bloomberg system in the following way. First, closing market data for all Refcorp zero-coupon bonds is collected. Next, the yields on these bonds are regressed on a set of variables such as functions of the maturity of the bond (similar to McCulloch and Kwon (1993), Nelson and Siegel (1987), or traditional cubic spline approaches). This approach typically results in the zero-coupon yield curve being fit with a high degree of accuracy; the standard deviation of residuals is usually on the order of four to five basis points. From the fitted yield curve, the yields for the constant maturity points can be estimated directly. The process is repeated using Treasury zerocoupon bonds and the premia are computed by differencing the estimated constant maturity yields.

Although the approach of using the Bloomberg fair value curves is necessitated by the one-month mismatch in maturity dates for Treasury and Refcorp zero-coupon bonds, this approach potentially has the advantage of minimizing the effects of illiquidity and measurement errors in prices on the empirical results. In particular, the estimated fitted values of the constant maturity yields from the regression are likely to be less sensitive to noise in the prices of individual zero-coupon bonds. Note also, that since the fair value curves for the Treasury and Refcorp zero-coupon bonds are calculated using the same algorithm and approach, the difference between the two curves should be largely unaffected by the interpolation methodology. Finally, the Bloomberg system uses coupon rather than principal strips in computing these fair value curves. This has the advantage of mitigating the effects of any reconstitution option value that might be present in principal strips (see the discusion in Daves and Ehrhardt (1993) and Jordan, Jorgensen, and Kuipers (2000)). Table 2 provides sum- 
mary statistics for the estimated flight-to-liquidity premia and Figure 1 graphs the flight-to-liquidity premium for the one-year and 30-year maturities.

\section{EMPIRICAL ANALYSIS}

Table 2 shows that there are significant liquidity-related premia in Treasury bond prices. The average premia range from about 10 to 16 basis points and are highly significant even after taking into account the serial correlation of the premia. Table 2 and Figure 1 also show that the premia vary significantly over time. The maximum values of the premia range from 90 basis points for the three-month premium to about 35 basis points for the seven-year premium. We note that the minimum premium for a number of the maturities is negative. This is clearly because there are undoubtedly measurement errors in the data adding noise to the estimates of the premia. Despite this noise, however, the mean estimates are statistically significant, indicating that the results are not entirely due to measurement errors.

It is straightforward to translate the differences in yields between the Treasury and Refcorp zero-coupon bonds into percentage price differences. The mean percentage price difference between the two bonds (measured as a percent of the Treasury zerocoupon bond price) ranges from .035 percent for the three-month maturity to 5.05 percent for the thirty-year maturity. The pricing differences for the longer-maturity bonds, however, can exceed 10 or even 15 percent.

At this point, we have shown that there are liquidity premia in the Treasury bond prices, but we have not directly linked these premia to the flight-to-liquidity phenomenon. To this end, we conduct a simple exploratory analysis in which we regress the premia on a variety of measures that may reflect on the popularity of Treasury bonds relative to other investment vehicles. It is important to acknowledge, however, that these variables are chosen for their intuitive appeal rather than on the basis of any theoretical model. Thus, our results should be interpreted cautiously and very much in the spirit of an exploratory investigation.

The first of these variables is the change in the consumer confidence index reported

by the Conference Board. A sudden decline in this widely-cited index may signal that 
there is a greater wariness among market participants holding riskier assets, perhaps encouraging some to migrate to the safe haven of Treasuries. If the difference in yields between Treasuries and Refcorp bonds represents a flight-to-liquidity premium, we might expect that there may be a negative relation between changes in consumer confidence and the premia. The data for consumer confidence are obtained from the Bloomberg system.

The second variable is the change in the amount of Treasury debt held by foreign investors. If U.S. investors, who presumably may benefit more from Treasury liquidity than many foreign holders of Treasury debt, suddenly begin to purchase Treasury debt from these foreign holders, the yield spread between Treasuries and Refcorp bonds could increase to reflect the increased popularity of holding Treasuries. The data on foreign ownership of Treasury bonds are obtained from the Federal Reserve Board.

The third variable is the percentage change in the amount of funds held in money market mutual funds. These funds are short-term nearly-riskless investments. When investors become concerned about the investment environment, some may have incentives to allocate their funds towards these near-money investments since their values are less likely to be affected by market turbulence. This suggests that if the difference in yields between Treasuries and Refcorp bonds represents a flight-to-liquidity premium, there could be a positive relation between this variable and the premia. The amount of funds held in money market mutual funds is included in the M3 monetary aggregate and the data are obtained from the Federal Reserve Board.

The fourth variable is the percentage change in the amount of funds held in equity mutual funds. The rationale for this variable mirrors that for the money market mutual fund variable. If investors feel confident, they are more likely to invest in equity mutual funds and to allow previous gains to remain in their accounts. Thus, we might expect that there would be a negative relation between yield differences between Treasury and Refcorp bonds and the amount of funds flowing into equity mutual funds. The data on the amount of funds held in equity mutual funds are taken from the monthly releases of the Investment Company Institute.

Note that in using these "flow of funds" variables, we are viewing them as potential indicators of public sentiment rather than as actual changes in the quantities of 
financial assets. If investors place more funds in equity mutual funds, of course, the mutual funds must purchase the equities from other market participants and total financial asset quantities may not change unless corporate equity issuance or repurchase programs are affected. In a market with heterogeneous investors, however, changes in the amounts held in mutual funds may well represent shifts in the household sector's perception of financial market risk.

The fifth variable reflects the change in the amount of Treasury securities available to investors as a result of the recent Treasury buyback program. In this program, which began in March 2000, the Treasury uses an auction format to repurchase longer term (and typically premium) bonds from market participants. If the spread between the yields of Refcorp and Treasury zero-coupon bonds reflects the relative liquidity of the two securities, then changes in the amount of Treasury bonds available to the market may affect the flight-to-liquidity premium. In particular, as the supply of Treasury bonds decreases through a Treasury buyback, investors may be willing to pay more of a premium to hold the now more-scarce remaining Treasury bonds. To examine this, we include the total market value (excluding accrued interest) of Treasury bonds repurchased during a month as the fifth explanatory variable. The data are collected directly from the U.S. Treasury new releases on buyback auction results. ${ }^{10}$

In addition to these variables, we include two other explanatory variables as controls in the regressions. First, as shown in Table 2, the yield differences between Treasuries and Refcorp bonds are serially correlated. To avoid the risk of finding a spurious relation between the yield spread and one of the explanatory variables with similar time series properties, we include the lagged value of the yield spread as an additional explanatory variable in the regression. Second, while there is effectively no default risk in the Refcorp bonds, there may be a market perception that there is default risk. To control for the possibility that the market believes that Refcorp bonds have credit risk, we include the spread between the Bloomberg index of five-year industrial AAA bond yields and the Bloomberg index of five-year industrial BBB1 bond yields as a second additional explanatory variable. These indicies are taken

${ }^{10} \mathrm{I}$ am particularly grateful to the referee for suggesting the inclusion of Treasury buybacks in the analysis. 
from the Bloomberg systems option-free fair value curves for industrial bonds with the indicated credit ratings. ${ }^{11}$ Thus, if the spread between Treasuries and Refcorp bonds is due to a belief that there is credit risk in the Refcorp bonds, this variable should explain most, if not all, of the difference. Since this variable represents the difference between two corporate yield indicies rather than the difference between a corporate yield and either the Treasury or Refcorp yield, we avoid the situation where the same variable appears on both the left and right sides of the regression. Table 3 reports summary statistics for the explanatory variables used in the regression.

The regression analysis is conducted by regressing the month-end liquidity spread on the lagged liquidity spread, the changes in the BBB-AAA credit spread, the consumer confidence index, the foreign holdings of Treasury bonds during the month, the percentage changes during the month in the aggregate amount of funds in money market and equity mutual funds, and the market value of bonds repurchased by the Treasury during the month. The regression results are summarized in Table 4. The results indicate that there is a strong relation between the premium and the measures of Treasury bond popularity. Thus, this exploratory analysis provides some support for viewing the difference between the yields of the Refcorp and Treasury bonds as a flight-to-liquidity premium.

As shown, the relation between the liquidity premium and changes in consumer confidence is almost always negative, and is significant for the maturities ranging from two years to 10 years. This is consistent with hypothesis that there is a movement towards the liquidity of Treasury bonds when consumer confidence drops. The results also suggest that Treasury bonds with intermediate maturities become more popular when confidence declines.

Table 4 also shows that there is a strong positive relation between the premium and the percentage change in funds held in money market mutual funds. The coefficient is positive for all maturities and is significant in five cases. Since money market mutual funds are conservative investments, this implies that the premium increases

${ }^{11} \mathrm{By}$ calculating the fair value curves using data from bonds without embedded options such as call features (or from bonds from which the estimated call premium has been extracted from the price), the Bloomberg option-free fair value indicies of yields should be largely unaffected by variation in option-like components. 
during periods where more funds are flowing into less-risky investments. Again, this is consistent with the interpretation that the premium increases when investors behave more cautiously.

The most significant explanatory variable of the five is the amount of the Treasury backback. The relation between the premium and the buyback amount is positive and statistically significant for all 11 maturities. This provides strong empirical support for the hypothesis that the premium reflects the relative importance of Treasuries as a safe haven for investors; as the supply of Treasury bonds declines, the remaining Treasury bonds become more valuable relative to Refcorp bonds.

The relation between the premium and changes in foreign holdings of U.S. Treasury debt is often negative, but is only significant for the two year maturity. Similarly, the relation between the premium and the percentage change in funds held in equity mutual funds is almost always negative, but is significant only for the thirty year maturity. This provides some additional support, however, for the view that the spread between Refcorp and Treasury yield reflects the level of confidence investors have in the market.

The lagged premium is significant for all the maturities, reflecting the fact that there is a high degree of persistence in the premium. Interestingly, the change in the credit spread is often significant, but is uniformly negative in sign. This strongly suggests that the premium is not a credit spread. If the difference between Refcorp and Treasury yields was due to perceived credit risk in the Refcorp bonds, we would expect the difference to be positively related to other credit spreads.

\section{ALTERNATIVE EXPLANATIONS}

In this section, we consider whether there are alternative explanations that could account for the difference in yields between Refcorp and Treasury bonds.

\subsection{Differential Taxation}

If there were differences in the way that Refcorp and Treasury zero-coupon bonds are taxed, then this might account for some of the flight-to-liquidity premium. In 
actuality, however, both Refcorp and Treasury zero-coupon bonds receive identical Federal income tax treatment. Specifically, both are treated as capital assets and are subject to the standard original issue discount provisions of Sections 1271-1275 of the Internal Revenue Code for Federal tax purposes. Futhermore, under title 12 of the US Code, interest (either accrued or accreted) on Treasury or Refcorp bonds is not taxable at the state level. In some states, however, capital gains on Treasury and agency bonds are taxable. In these states, however, the tax treatment given to Treasury and Refcorp zero-coupon bonds is again symmetric. Thus, it is unlikely that either the level or the variation in the flight-to-liquidity premium can be attributed to differences in tax treatment.

\subsection{Bid-Ask Spreads}

Since Treasury securities are more liquid that Refcorp bonds, it is not surprising that Treasury securities have smaller bid-ask spreads. The issue, however, is whether the difference in the size of the bid-ask spreads is such that it might account for the flightto-liquidity premium. To this end, we spoke with several Wall Street firms that make markets in both Treasury and Refcorp zero-coupon bonds. For institutional investors, the typical bid-ask spread for a Treasury zero-coupon bond is on the order to two to three ticks or 32nds of a dollar per $\$ 100$ notional face amount. The typical bid-ask spread for Refcorp zero-coupon bonds is slightly larger, usually on the order of three to four ticks. Spreads of this size translate into yield spreads of only about a basis point or two. Since our analysis is based on the midpoints of market quotes, it is unlikely that the difference in the sizes of the bid-ask spread can explain much of the flight-to-liquidity premium. Even more clearly, differences in the bid-ask spreads are unlikely to explain the systematic time variation in the flight-to-liquidity premium.

It is important to acknowledge, however, that while bid-ask spreads on Treasury and Refcorp zero-coupon bonds may be somewhat comparable, the sizes of the bid and offer markets at the quoted spreads may be very different. For example, an institutional investor who may need to liquidate his portfolio at some future point in time might well choose to avoid Refcorp strips (if they were priced at yields very close to those for Treasury zero-coupon bonds) since the investor might not be able to liqui- 
date his position in a timely manner. ${ }^{12}$ Consistent with the opening quotation by Alan Greenspan about the desire to "disengage," the willingness of investors to pay for a flight-to-liquidity premium in Treasury bonds may be a reflection of their unwillingness to hold Refcorp bonds at a time when they may wish to liquidate positions.

\subsection{Differential Repo Rates}

As discussed by Duffie (1996), Longstaff (2000), Liu and Longstaff (2000), and many others, institutional investors often leverage their positions in Treasury and Agency securities through the use of security repurchase or repo contracts. If there was a systematic difference between the borrowing or repo rates associated with Treasury and Refcorp zero-coupon bonds, then there might rationally be a valuation difference between the two securities to reflect the present value benefit of the reduced financing cost. Our discussions with the Treasury and Agency bond dealers indicated that few Treasury zero-coupon bonds could be financed at special repo rates during most of the sample period. ${ }^{13}$ Thus, the premium is unlikely to be due to the difference between general collateral repo rates for Refcorp zero-coupon bonds and special repo rates for Treasury zero-coupon bonds. This leaves open the possibility, however, that there may be a difference between the general collateral rates available for Treasury and Agency collateral. To test this, we collected monthly data from 1991 to 2001 on general Treasury and Agency collateral repo rates from the Bloomberg system. The mean difference between the two repo rates was only .25 basis points. Thus, differences in the repo rates between Refcorp and Treasury zero-coupon bonds probably cannot account for the flight-to-liquidity premium.

\subsection{Regulatory and Legal Restrictions}

Many institutions such as mutual funds, insurance companies, commercial banks, pension and retirement funds, local government entities, etc. have various regulatory and legal restrictions on the types of securities they are permitted to invest in. If, for example, there were many investors who were allowed to invest in Treasury zero-

${ }^{12} \mathrm{I}$ am indebted to the referee for these insights.

${ }^{13}$ For a discussion of special repo rates, see Duffie (1996), Jordan and Jordan (1997), and Liu, Longstaff, and Mandell (2001). 
coupon bonds, but not Refcorp zero-coupon bonds, then clientele differences might offer some explanation for premium. To explore this issue, we did an extensive search for institutional investors who had posted their list of permissible investments on the web. These institutions included several dozen states, counties, cities, mutual funds, universities, and other entities. In virtually every case, the institutions were explicitly allowed to hold both Treasury and Agency securities.

\section{CONCLUSION}

This paper examines whether there is a flight-to-liquidity premium in U.S. Treasury bond prices. This is done by comparing the prices of Treasury zero-coupon bonds with those of Refcorp zero-coupon bonds. By their nature, Refcorp bonds are effectively guaranteed by the U.S. Treasury and have the same default-free status as Treasury bonds. Thus, the differences between Treasury and Refcorp bond prices can be attributed entirely to liquidity.

We find that the yield spread between Refcorp and Treasury bonds is statistically and economically significant and is directly related to a number of variables such as consumer confidence, the amount of Treasury bonds repurchased by the Treasury, and flows into equity and money market mutual funds. These results are consistent with the view that the difference in yields reflects the willingness of investors to pay a premium for the liquidity of Treasury bonds when markets are unsettled. This study provides evidence supportive of the existence of a significant flight-to-liquidity component in Treasury bond prices. 


\section{REFERENCES}

Amihud, Y., and Mendelson, H. 1991. Liquidity, maturity, and the yields on U. S. Treasury securities. The Journal of Finance 46 (September): 1411-25.

Bernanke, B., and Gertler, M. 1995. Inside the black box: The credit channel of monetary policy transmission. Journal of Economic Perspectives 9 (Autumn): 27-48.

Boudoukh, J., and Whitelaw, R. F. 1991. The benchmark effect in the Japanese Government bond market. The Journal of Fixed Income (September): 52-59.

Boudoukh, J., and Whitelaw, R. F. 1993. Liquidity as a choice variable: A lesson from the Japanese Government bond market. The Review of Financial Studies 6 (Summer): 265-92.

Brenner, M., Eldor, R., and Hauser, S. 2001. The price of options illiquidity. Journal of Finance 56 (April): 789-805.

Daves, P. R., and Ehrhardt, M. C. 1993. Liquidity, reconstitution, and the value of U. S. Treasury strips. The Journal of Finance 48 (March): 315-29.

Diamond, D., and Dybvig, P. 1983. Bank runs, deposit insurance and liquidity. Journal of Political Economy 91 (June): 401-19.

Duffee, G. 1999. Estimating the price of default risk. The Review of Financial Studies 12 (Spring): 197-226.

Duffie, D.. 1996. Special repo rates. The Journal of Finance 51 (June): 493-526.

Duffie, D., and Singleton, K. 1997. An econometric model of the term structure of interest rate swap spreads. The Journal of Finance 52 (September): 1287-1321.

Duffie, D., and Singleton, K. 1999. Modeling term structures of defaultable bonds. The Review of Financial Studies 12 (Special Issue): 687-720.

Grinblatt, M., and Longstaff, F. A. 2000. Financial innovation and the role of derivative securities: An empirical analysis of the U.S. Treasury's STRIPS program. Journal 
of Finance 55 (June): 1415-36.

Holmström, B., and Tirole, J. 1996. Modeling aggregate liquidity. American Economic Review 86 (May): 187-91.

Holmström, B., and Tirole, J. 1998. Private and public supply of liquidity. Journal of Political Economy 106 (February): 1-40.

Holmström, B., and Tirole, J. 2001. LAPM: A liquidity-based asset pricing model. Journal of Finance 56 (October): 1837-67.

Jordan, B., and Jordan, S. 1997. Special repo rates: An empirical analysis. The Journal of Finance 52 (December): 2051-72.

Jordan, B., and Kuipers, F. 1997. Negative option values are possible: The impact of Treasury bond futures on the cash U.S. Treasury market. Journal of Financial Economics 46 (October): 67-102.

Jordan, B., Jorgensen, R. and Kuipers, D. 2000. The relative pricing of U.S. Treasury STRIPS. Journal of Financial Economics 56 (April): 89-123.

Kamara, A. 1988. Market trading structures and asset pricing: Evidence from the Treasury-bill markets. Review of Financial Studies 1 (Winter): 357-75.

Kamara, A. 1994. Liquidity, taxes, and short-term Treasury yields. Journal of Financial and Quantitative Analysis 29 (September): 403-17.

Lippman, S., and McCall, J. 1986. An operational measure of liquidity. The American Economic Review 76 (March): 43-55.

Liu, J., and Longstaff, F. A. 2000. Losing money on arbitrages: Optimal dynamic portfolio choice in markets with arbitrage opportunities. Working paper: UCLA.

Liu, J., Longstaff, F. A. and Mandell, R. 2001. The market price of credit risk: An empirical analysis of interest rate swap spreads. Working paper: UCLA.

Longstaff, F. A. 1992. Are negative option prices possible? The callable U.S. Treasury bond puzzle. The Journal of Business 65 (October): 571-92. 
Longstaff, F. A. 1995. How much can marketability affect security values? The Journal of Finance 50 (December): 1767-74.

Longstaff, F. A. 2000. The term structure of very short-term rates: New evidence for the expectations hypothesis. Journal of Financial Economics 58 (December): 397-415.

Longstaff, F. A. 2001. Optimal portfolio choice and the valuation of illiquid assets. Review of Financial Studies 14 (Summer): 407-31.

McCulloch, J., and Kwon, H. 1993. US term structure data, 1947-1991. Working paper 93-6: The Ohio State University.

Nelson, C., and Siegel, A. 1987. Parsimonious modelling of yield curves. Journal of Business 60 (October): 473-89.

Woodford, M. 1990. Public debt as private liquidity. The American Economic Review 80 (May): 382-88. 
Table 1

Refcorp Bonds Issued. This table provides summary information about the Refcorp bond issues from which Refcorp Strips are derived. The amount issued is in \$millions. The data are from the Bloomberg system.

\begin{tabular}{|c|c|c|c|c|c|}
\hline Bond & Coupon Rate & Maturity & Amt. Issued & Issue Date & Coupon Payment Dates \\
\hline Refcorp & 8.125 & 15 Oct 2019 & 4,500 & 15 Oct 1989 & Apr 15, Oct 15 \\
\hline Refcorp & 8.625 & 15 Jan 2021 & 4,950 & 15 Jan 1991 & Jan 15, Jul 15 \\
\hline Refcorp & 8.625 & 15 Jan 2030 & 5,000 & 15 Jan 1990 & Jan 15 , Jul 15 \\
\hline Refcorp & 8.875 & 15 Jul 2020 & 5,000 & 15 Jul 1990 & Jan 15 , Jul 15 \\
\hline Refcorp & 8.875 & 15 Apr 2030 & 5,500 & 15 Apr 1990 & Apr 15, Oct 15 \\
\hline Refcorp & 9.375 & 15 Oct 2020 & 5,000 & 16 Oct 1990 & Apr 15, Oct 15 \\
\hline
\end{tabular}


Table 2

Summary Statistics for the Flight-to-Liquidity Premia in Treasury Bond Prices. This table reports summary statistics for the flight-toliquidity premia for the indicated maturities, where the premium is computed as the difference between the yields on Refcorp and Treasury zero-coupon bonds with the same maturity. The $t$-statistic for the mean is corrected for first-order serial correlation. The data are monthly from April 1991 to March 2001, and the number of observations for each time series is 120. The flight-to-liquidity premia are measured in basis points.

\begin{tabular}{|c|c|c|c|c|c|c|c|}
\hline $\begin{array}{l}\text { Maturity } \\
\text { in Years }\end{array}$ & Mean & $\begin{array}{l}\text { Standard } \\
\text { Deviation }\end{array}$ & Minimum & Median & Maximum & $\rho$ & $\begin{array}{r}t \text {-Statistic } \\
\text { for the Mean }\end{array}$ \\
\hline .25 & 13.83 & 17.14 & -35.00 & 11.00 & 90.00 & .601 & 4.45 \\
\hline .50 & 11.61 & 11.66 & -28.00 & 10.00 & 62.00 & .597 & 5.52 \\
\hline 1.00 & 11.37 & 13.46 & -13.00 & 8.00 & 80.00 & .823 & 2.94 \\
\hline 2.00 & 9.35 & 10.28 & -9.00 & 6.00 & 46.00 & .767 & 3.68 \\
\hline 3.00 & 9.66 & 9.78 & -10.00 & 7.00 & 44.00 & .770 & 3.96 \\
\hline 4.00 & 10.04 & 9.54 & -7.00 & 6.00 & 45.00 & .760 & 4.32 \\
\hline 5.00 & 9.99 & 9.16 & -6.00 & 7.00 & 41.00 & .752 & 4.56 \\
\hline 7.00 & 11.41 & 8.59 & -5.00 & 10.00 & 35.00 & .629 & 7.00 \\
\hline 10.00 & 13.13 & 7.40 & .00 & 12.00 & 38.00 & .726 & 7.84 \\
\hline 20.00 & 14.93 & 7.58 & 3.00 & 13.00 & 44.00 & .815 & 7.03 \\
\hline 30.00 & 16.28 & 9.33 & 2.00 & 15.00 & 54.00 & .822 & 6.11 \\
\hline
\end{tabular}




\section{Table 3}

Summary Statistics for the Explanatory Variables in the Flight-to-Liquidity Regression. This table reports summary statistics for the variables used as explanatory variables in the flight-to-liquidity regression. The variable $\Delta$ Spread is the monthly change in the spread between the BBB and AAA corporate yields measured in basis points. The variable $\Delta$ Confidence is the monthly change in the Conference Board Index of Consumer Confidence. The variable $\Delta$ Foreign Holdings is the monthly change in the total amount of foreign holdings of U.S. Treasury bonds measured in billions of dollars. MM Mutual Fund Percent is the monthly percentage change in the aggregate amount of funds in money market mutual funds. Equity Mutual Fund Percent is the monthly percentage change in the aggregate amount of funds in equity mutual funds. Treasury Buyback is the market value in \$billions of all Treasury buybacks during the month. The data are monthly from April 1991 to February 2001 , and Buyback is the market value in \$billions of all Treasury
the number of observations for each time series is 118.

\begin{tabular}{|c|c|c|c|c|c|c|}
\hline Variable & Mean & $\begin{array}{l}\text { Standard } \\
\text { Deviation }\end{array}$ & Minimum & Median & Maximum & $\rho$ \\
\hline$\Delta$ Spread & -.025 & 7.526 & -25.000 & .000 & 24.000 & -.057 \\
\hline$\Delta$ Confidence & .253 & 5.264 & -12.900 & -.200 & 12.500 & .107 \\
\hline$\Delta$ Foreign Holdings & 5.881 & 12.073 & -17.932 & 5.046 & 45.391 & .295 \\
\hline MM Mutual Fund Percent & 1.045 & 1.044 & -2.198 & 1.105 & 3.704 & .595 \\
\hline Equity Mutual Fund Percent & 2.149 & 4.111 & -15.881 & 2.856 & 11.648 & -.098 \\
\hline Treasury Buyback & .374 & 1.174 & .000 & .000 & 6.115 & .908 \\
\hline
\end{tabular}




\section{Table 4}

Regression Results. This table reports the estimated coefficients and $t$ statistics from the regression of the flight-to-liquidity premium on the lagged flight-to-liquidity premium and the explanatory variables described in Table 3. The data are monthly from April 1991 to February $2001 .{ }^{*}$ denotes signficance at the 10 percent level; ${ }^{* *}$ denotes significance at the 5 percent level.

$$
\begin{aligned}
\text { Premium }_{t}=\beta_{0} & +\beta_{1} \text { Premium }_{t-1} \\
& +\beta_{2} \Delta \text { Spread }_{t} \\
& +\beta_{3} \Delta \text { Confidence }_{t} \\
& +\beta_{4} \Delta \text { Foreign Holdings }_{t} \\
& +\beta_{5} \text { MM Mutual Fund Percent } t \\
& +\beta_{6} \text { Equity Mutual Fund Percent }_{t} \\
& +\beta_{7} \text { TreasuryBuyback }_{t}+\epsilon_{t}
\end{aligned}
$$

\begin{tabular}{|c|c|c|c|c|c|c|c|c|c|c|c|c|c|c|c|c|c|}
\hline Maturity & $\beta_{0}$ & $\beta_{1}$ & $\beta_{2}$ & $\beta_{3}$ & $\beta_{4}$ & $\beta_{5}$ & $\beta_{6}$ & $\beta_{7}$ & $t_{\beta_{0}}$ & $t_{\beta_{1}}$ & $t_{\beta_{2}}$ & $t_{\beta_{3}}$ & $t_{\beta_{4}}$ & $t_{\beta_{5}}$ & $t_{\beta_{6}}$ & $t_{\beta_{7}}$ & $R^{2}$ \\
\hline .25 & .069 & .469 & -.342 & .0015 & -.0009 & .524 & -.394 & .032 & $3.12^{* *}$ & $5.68^{* *}$ & $-2.12^{* *}$ & .68 & -.89 & .45 & -1.36 & $2.84^{* *}$ & .411 \\
\hline .50 & .046 & .495 & -.266 & .0013 & -.0009 & 1.702 & -.275 & .015 & $2.91^{* *}$ & $5.98^{* *}$ & $-2.37^{* *}$ & .81 & -1.27 & $2.09^{* *}$ & -1.37 & $1.91^{*}$ & .389 \\
\hline 1.00 & .018 & .616 & -.149 & -.0005 & -.0004 & 1.387 & .162 & .030 & 1.54 & $8.04^{* *}$ & $-1.66^{*}$ & -.38 & -.74 & $2.10^{* *}$ & 1.02 & $4.06^{* *}$ & .694 \\
\hline 2.00 & .029 & .580 & -.165 & -.0024 & -.0010 & 1.360 & -.191 & .017 & $2.98^{* *}$ & $7.71^{* *}$ & $-2.13^{* *}$ & $-2.17^{* *}$ & $-1.93^{*}$ & $2.29^{* *}$ & -1.37 & $2.72^{* *}$ & .655 \\
\hline 3.00 & .033 & .511 & -.193 & -.0023 & -.0006 & .767 & -.029 & .026 & $3.43^{* *}$ & $6.85^{* *}$ & $-2.76^{* *}$ & $-2.27^{* *}$ & -1.25 & 1.48 & -.23 & $4.45^{* *}$ & .674 \\
\hline 4.00 & .031 & .580 & -.171 & -.0028 & .0001 & .419 & -.076 & .023 & $3.06^{* *}$ & $7.85^{* *}$ & $-2.37^{* *}$ & $-2.71^{* *}$ & .14 & .78 & -.57 & $3.92^{* *}$ & .650 \\
\hline 5.00 & .028 & .622 & -.205 & -.0027 & -.0000 & .748 & -.162 & .015 & $2.84^{* *}$ & $8.55^{* *}$ & $-2.94^{* *}$ & $-2.72^{* *}$ & -.05 & 1.44 & -1.28 & $2.70^{* *}$ & .629 \\
\hline 7.00 & .040 & .473 & -.071 & -.0023 & .0002 & 1.049 & .024 & .019 & $3.25^{* *}$ & $5.84^{* *}$ & -.89 & $-1.97^{* *}$ & .43 & $1.78^{*}$ & .17 & $3.12^{* *}$ & .480 \\
\hline 10.00 & .067 & .430 & -.108 & -.0015 & .0001 & .065 & -.148 & .025 & $5.68^{* *}$ & $4.91^{* *}$ & $-1.86^{*}$ & $-1.74^{*}$ & .38 & .15 & -1.38 & $4.56^{* *}$ & .619 \\
\hline 20.00 & .049 & .581 & -.060 & .0002 & .0000 & .751 & -.091 & .020 & $4.42^{* *}$ & $7.74^{* *}$ & -1.16 & .29 & .02 & $1.96^{* *}$ & -.96 & $3.97^{* *}$ & .719 \\
\hline 30.00 & .045 & .716 & -.069 & -.0003 & -.0002 & .298 & -.257 & .012 & $3.65^{* *}$ & $9.73^{* *}$ & -1.06 & -.36 & -.45 & .62 & $-2.08^{* *}$ & $1.98^{* *}$ & .711 \\
\hline
\end{tabular}




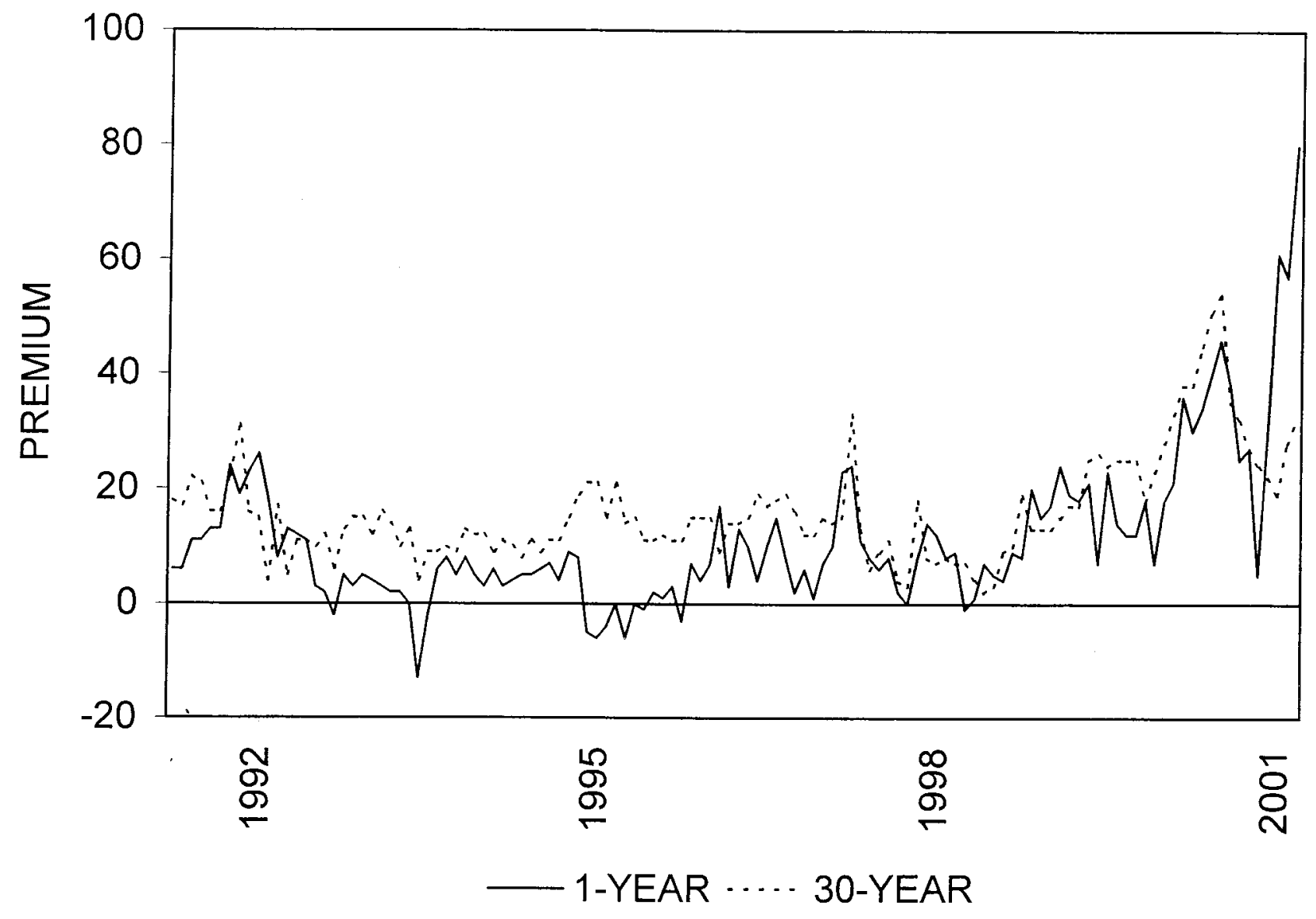


Figure 1. This graph shows the flight-to-liquidity premia for the 1-year and 30-year maturities. The data is monthly from April 1991 to March 2001. The flight-to-liquidity premia are measured in basis points. 